\title{
THE IMPORTANCE OF MASTERING FOREIGN LANGUAGES IN DEVELOPING HOSPITALITY AND TOURISM INDUSTRIES.
}

\author{
Acep, Unang, Rahayu \\ AKPAR NHI Bandung
}

\begin{abstract}
This study aims at offering some thoughts that cultural differences influence a great deal in hospitality and tourism industries. In Indonesia English is a second language whereby occupational background in the past still dominates our language structure. Indonesia was occupied by the Dutch for 3 and half decades then by the Japanese for 3 and half years. Lacking of vocabulary items, Indonesian Language still use foreign languages such those borrowed from Dutch, English, Italian, Portuguese and Arabic.Cultural differences also influences Indonesian way of using the English expressions at hospitality industries. Mastering foreign languages is very important in developing hospitality industries in Indonesia. The main findings of my research are : those motivated students learn foreign languages better, those having good learning strategies master foreign languages better, and those mastering foreign languages work successfully at hospitality and tourism industries.
\end{abstract}

Keywords:developing,languages, hospitality,strategies,motivated,success.

\section{Introduction}

In Indonesia English is as International language used as a compulsory language taught from elementary to university degree, and English is the foreign language which should be mastered because most of the literature from many angles of knowledge is written in English. Other foreign languages such as French, Mandarin, Japanese and Arabic are learnt as optional foreign languages. This problem makes most of Indonesian students face difficulties in understanding spoken and written foreign languages especially English as the first International language to master in Indonesia. Other influencing problem is that the Indonesian structure is totally different from English or other foreign languages mentioned above. For example, in English, Subject is usually followed by a verb, while in Indonesian language, Subject can be followed by a noun or adjective.

The Indonesian youth's oath spoken in 1928 is a bench mark for Indonesian unity strengthened by the statement that the Indonesian language is the for unity and identity of Indonesian country. Though there are many tribes living in Indonesia from the West to the East of Indonesia besides half-mixed ones (Indo-Europe, Indo-America, Indo-Australia etc.) Indonesian language is the national language for communication. The love of using Indonesian language must be maintained and developed. However, foreign languages terms especially English are inevitable due to the development of knowledge and foreign 
companies establishment. Media plays important role in contributing new terms for Indonesian language.

There are two things which should be considered when using foreign terms such as English as mentioned by Sugono et.al. (2003:2): "Pertama, harus ada kesinambungan antara hakikat bahasa dulu dan sekarang;artinya bahasa nasional jangan kehilangan jati dirinya. Kedua, penyerapan unsur bahasa asing harus mempertajam daya ungkap pemakai bahasa Indonesia dan harus memungkinkan orang menyatakan isi hatinya dengan tepat dan cermat". Which means " the first, there must be a relationship between the past and the present language essence; meaning that the national language should not lose its identity. Second, foreign language usage must sharpen its correspondence in Indonesian and must allow people to speak their hearts exactly and precisely". This statement implies that whatever kinds of foreign languages spoken by everybody at hospitality and tourism world in Indonesia, understanding the meaning is essential in both Indonesian and foreign languages.

Understanding foreign languages in hospitality and tourism industries is a must, because the establishments of international hotels and tourisms business in Indonesia will develop widely and run successfully with the mastery and involvement of foreign languages. Therefore, the study of how far foreign languages mastery is needed.

\section{Literature Review}

\section{Local Situation}

The studies of learning strategies in relation to motivation and attitudes have been discussed since 1970's to the present moment. In Canadian context (see Gardner and Lambert 1985) where students from different backgrounds of studies were investigated whether to have internal or external motivation. The findings showed that students who had high motivation and positive attitudes, were successful in learning foreign languages such as French and English. In Asia (see Lukmani 1975) an investigation towards motivation and attitudes were also done with the subjects of students who were trained to be motivated in learning foreign language such as English. The results showed that those having both external and internal motivation were successful in getting jobs in various companies. In this research integrated motivation that was a combination between external and internal also a good example of motivation that students had to possess. In England (see Rahayu 1995) similar investigation towards motivation and attitudes was also carried out. The subjects of the research were Indonesian students taking master's degree in England. Their English knowledge were not sufficient, therefore they took English courses from different places in England. The writer (from 1994 to 1995) was helping them with the English knowledge to get higher score of TOEFL at the same time the investigation of their motivation and attitudes were investigated. The result was that their English were much better than before, because they had a private English course related to their TOEFL preparation. Their motivations and attitudes were also developing 
during staying in England besides the demand of their studies where understanding English was very important to understand their subjects. In this research those having higher motivation and positive attitudes had higher score in TOEFL tests administered in England.

In 2014 At Akademi Pariwisata (AKPAR NHI) Bandung, Indonesia, whereby this research was administered, English is taught almost every day, but for the intermediate to advance levels let us say semester 5 to 6 English is taught once in a week. This is not because their English get better, their concentration on their subjects and other lessons are more prioritised than English lesson. The students' background vary from talented to less talented ones in foreign languages. In the entrance test, AKPAR NHI management held written and oral tests to know whether they would be accepted to continue their studies at AKPAR NHI or not. The needs of mastering foreign languages especially English is compulsory. When the students have accomplished their studies they usually write an application letter in English because they apply for a job in mostly international hotels in domestic or overseas, and for field study practice. Of course their ability in spoken English has to be shown at the interview. On the other hand, the lecturers have professionals teaching backgrounds and most them are from senior lecturers of SekolahTinggi Pariwisata Bandung (STPB) whose experiences in teaching and working at hospitality and tourism industries have long list of journey. However, both students and lecturers need to develop their learning and teaching motivation and attitudes because lecturers are some parts of the key success of their students. Motivating lecturers can also produce motivated students, especially in their learning motivation and their attitudes.

\section{Aims of this research}

To know more about the students' learning strategies, and to know how the students develop themselves in Hospitality and Tourism industries. In this research only the student's learning strategies were investigated.

\section{The Research Questions}

1. What are the student's learning strategies in mastering foreign languages?

2. How do the students develop themselves in Hospitality and Tourism Industries?

\section{Methodology}

In this research descriptive methodology was used to explore the students' learning strategies in mastering foreign language. As mentioned by (Selliger and Schollamy 1990:124, in Alwasilah (1991:14) “ Descriptive research involves a collection of techniques used to specify, delineate, or describe naturally occurring phenomena without experimental manipulation. Descriptive research is used to establish the existence of phenomena by explicitly describing them". This implies that in a descriptive research, data have to be accurate, no manipulation, and data should be better taken directly from the research sample. The data were collected from questionnaire and then chosen and tabulated to find similarities. The main data were taken from 46 AKPAR NHI students from Hotel Management division. 


\section{Results and Discussion}

1. The student's learning strategies in mastering foreign language

Table 1

The Students' Learning Strategies in Mastering Foreign Language

\begin{tabular}{|l|l|l|l|}
\hline No. & \multicolumn{1}{|c|}{ At home } & \multicolumn{1}{c|}{ At campus } & \multicolumn{1}{c|}{ Outdoors } \\
\hline & Reading English & Listening to instructor's & Practicing English with \\
& lesson, magazine, & explanations, asking questions to & friends, joining \\
& novel, newspaper. & instructor, friends, answering & conversation club, reading, \\
& Listening to English & questions, participating in & going to library, watching \\
& movies, taking an English \\
& songs, watching & discussions, writing, an essay, note & course. \\
& television in English & taking, practicing dialogues, & \\
& program, writing & thinking, watching, reading, just & \\
& essay, diary & sitting. & \\
\hline
\end{tabular}

The table above shows that at home most of the students have something to do to understand foreign language in this case English. At least they try to learn English from different sources. Watching television in English program and listening to English songs are supporting activities to gain English knowledge and culture. Writing essay is also good at enhancing writing skill besides practicing the use of vocabulary items. To note here, the students were taught academic essay writing and they were given task to accomplish an essay with some topic given then presented in class. At campus some students paid attention to the foreign language lesson by listening and asking questions to the teacher's instructions, and doing all the activities that the students were supposed to do when having a lecture. Outdoors or out of home or campus, the students practiced their English among them, and some of them joined a conversation club to practice with other community. These findings imply that the students have awareness of the importance in mastering foreign language such as English. They have to understand it, they need to master it due to the future requirements when they seek for jobs and when they work as one of the hospitality or tourism industries employees.

2. The students' activity in developing themselves in Hospitality and Tourism Industries

Table 2

The Studens' Activity in Developing Themselves in Hospitality and Tourism Industries

\begin{tabular}{|l|l|l|l|}
\hline No. & \multicolumn{1}{|c|}{ At home } & \multicolumn{1}{c|}{ At campus } & \multicolumn{1}{c|}{ Outdoors } \\
\hline & $\begin{array}{l}\text { Reviewing lesson, } \\
\text { reading English } \\
\text { magazine, watching } \\
\begin{array}{l}\text { English television } \\
\text { programs, nothing. }\end{array}\end{array}$ & $\begin{array}{l}\text { Studying, practicing: in the kitchen, } \\
\text { simulation rooms, having } \\
\text { discussions, going to library. }\end{array}$ & $\begin{array}{l}\text { Working at hotel for field } \\
\text { study practice, travelling, } \\
\text { camping, jogging. }\end{array}$ \\
\hline
\end{tabular}

This table shows that some students reviewed lesson at home besides reading English magazine, watching English television programs, but a few mentioned nothing. At campus they studied and practised cooking or making cakes in the 
kitchen. Some practised their knowledge of room division in the simulation rooms Some preferred going to library. While outdoors, they practiced working at a hotel to fulfil one of the requirements for field study practice. They travelled, and some mentioned camping, and jogging. These findings imply that the students have tried to develop themselves preparing for their future some day when they have already finished their studies. They must be ready to work as hoteliers and tourism providers, and of course the mastery of English as foreign language will be very much needed. What we learn from these findings is that they remind the hospitality and tourism providers that the human resources candidate of hospitality and tourism industries need preparing long before they serve in the real worlds.

As a note: evaluating their English capability in the classroom from the results of mid-test and final -test, their English was in average level. Only a few students who had better score than the others.

Learning from the above findings, let us return to theoretical background which support learning strategies, what make the students develop themselves in the hospitality and tourism industries. Let us see what motivate every students behind their learning.

Oxford (1990:1, see also Nisbet 1986 Chamot 1987, Wenden. 1987 Ellis 1990,) defines it as: "Learning strategies are steps taken by students to enhance their own learning. Strategies are important for learners because they are tools for active, self-directed involvement which is essential for developing communicative competence."

These are some strategies for students to know how to learn.

-Know yourself : by measuring some weaknesses and strengths in learning, then choose the most suitable way of learning. Many factors influencing learning, but think the best way whether by reading, paying attention, listening or doing things. Get to know well as the way the instructor teaches to adapt.

-Manage your time and life : by learning to manage time and control life pattern such as determining the aims of learning and how to do it.

-Improve your concentration : by learning how to focus on learning in the class room for example: smart students do not take longer in studying than less smart students, because smart students can use the time effectively.

- Know what study means and how to do it: there are four routine a good student has to go through, those are: pre-reading, studying in the classroom, repeating at home, studying in depth.

- Become an active reader: by reading a lot of books and asking a lot of questions actively after accomplishing reading the lesson material.

- Become an active writer: by writing we will put forward our ideas a lot more, our thoughts are sharpened.

-Build listening and note taking skills : by being an active listener while writing only important things in the class room and repeat it at home.

-Know how to study for and take exams : by repeating the lesson and preparing the material before having an examination will produce something better.

Talking about developing Hospitality and Tourism industries, let us take a look at some view points concerning kinds of service that should be provided. 
According to Martin and Kandampully $(2002,2003)$ ' future trends for tourism seem to suggest that travellers will be especially concerned with not just being "there"but with participating, learning and experiencing the place they visit. Some tourism interests include:cultural and heritage tourism, ecotourism, educational tourism, nature based, enviromental, and sustainable tourism.This statement implies that a tourist coming to a country with some bunch of questions to answer before going to some places of interests. S/he may ask questions themselves such as what, how, when, which, where etc. then when they arrive at the places they intend to be, They may say 'oh, I see, then, if that so, etc'. Therefore, hospitality and tourism developers or providers have to be ready with everything that may happen. In this case, hospitality and tourism provider have to prepare themselves with excellent service for customer. Once there was a proverb saying that customer is a king, now customer may be more than a king, or customer is still a king. Here are what people say about customer service :Customer service means taking care of me, I call customer service when I have a problem. Customer service is talking to a real person rather than a computer. Customer service is being nice to guests. Customer service is helping and then helping some more. Those expressions are the hopes from customer since hospitality industry is very closely associated with the tourism industry and hospitality.It is essentially a service business enterprise. Because Customer service is intangible, Customer service should reflect the people side of the hospitality business. Services seem perishible as well that means they can not be stored only produced when needed by customer, remember that the customer is king. The customer is the reason we exist. Without our customers we have nothing. Each of this statements reflects a customer orientation- a view that the customer is vital to the nature and success of one's business. Take care of the employees and they'll take care of your customers. Consistency is the key to achieving quality customer service, therefore increasing the number of service, means achieving successes and significantly reduce the number of service failures. Serving customer needs to be balanced by good attitude of customer service staffs. One way attitudes are communicated to guests is through body language. In fact, what some communication experts maintain that our body language, our actions and posture show our thoughts and feelings. For example: a smile on your face is a wonderful thing to see. It is not uncommon, however, for service providers to be so busy performing their jobs that they forget about the importance of a smile. Making eye contact with customers means communicating sincerity, interest and trustworthy. In contrast, lack of eye contact reflects disinterest and insincerity. Eye contact is vital in all interactions with customers, but it is particularly important when a problem or complaint arises. Some Indonesian customer service staffs are not accustomed to making eye contact when talking to customers, this is due to our cultural habit that, making eye contact may mean impolite or challenging when eye contact becomes eye a staring. Proper grooming is another way a customer service staff shows attitude of concern for customers. Clean faces, hands, fingernails, and clothes remain the bottom line of acceptable hospitality. Attitudes are exhibited through the intonations of the words spoken and emphasis placed on certain selected words. For example: the word" good morning" can reflect any of the following meanings:-I'm rely glad to see you-I recognize you, Glad to see you again, -What are you doing here?-I'm too busy, Don't bother me 
now,-I'm bored and couldn't care less about you,-Good-bye, Come again. Put a smile into your voice.

It is further described that a common hospitality phenomenon, but rarely recognized and little understood, is called metamorphosis. Attitudes are supposed to be contagious like a fire spreads through dry bush, attitudes are caught from one person to another. Every one on a hospitality service team is vulnerable. The actual words that we use with guests also reveal a great deal about our ability to provide quality customer service. The ability to say the right thing at the right time in the right way is the essence of quality verbal communication. Further, it is discussed that as a hospitality service provider, what you say to customers should be appropriate to the situation. To be appropriate, verbal communication must also be tactful and inoffensive. Moreover, the communication should contribute to customer enjoyment, relaxation, and feelings of hospitality. Customers should never be made to feel uncomfortable or embarrassed by a careless, callous, or otherwise stupid comment from anyone in the operation. Polite words such as "please', I'm sorry or thank you are always tactful. Calling customers by names is always appropriate. Yet using a guest's name at the right time and the right way is a hospitality skill that customers generally expect. The use of customer names reflects a special caring for customers. That is why it is very important to master foreign languages especially English to avoid misunderstanding or miscommunication. Understanding the customer's cultural background is an advantage, because the need to be understood may mean connecting with customers on a feeling level-getting to enjoy them and having them enjoy us in return. For example: reading the guests' nonverbal and verbal helps the service provider to be aware of a customer's particular need which includes the customers'age, his or her attire, guest body language, verbal abilities as well as his or her tone of voice.The customers need to feel welcome because hospitality customers need to feel like they belong, that they are insiders. Customers also need for comfort this means generating a psychological atmosphere of relaxation and enjoyment, which, after all, is what hospitality is all about. Above all, rapport embodies the attitudes, feelings, and relationships that help establish mutual respect between customers and service providers. Without rapport, effective communication breaks down, and service quality suffers. Mastering foreign language such as English is a must in hospitality and tourism in industries. In Bali, for example whereby many tourism attractions spread out, cheap to luxurious hotels built up almost every seasons. Foreign tourists come to Bali for some reasons. Without mastering foreign languages, it is very difficult to attract tourists to come and stay in Bali. They need to communicate in English at least, so their business communication will run as they wish. One of this examples would be wise if hospitality and tourism providers become familiar with the five forbidden phrases such as:1.I don't know We can't do that You'll have to...Hang on a second, 2. I'll be right back, 3.Saying' no' at the beginning of a sentence, I will find out, What I can do is.,4. May I help you to...,.May I call you back in a few minutes, 5.Yes. What we learn from this, is that Customers expect problems to be handled not only expeditiously, but also smoothly, calmly, and tactfully. Further, we are given examples of solutions such as The five Problem-solving imperatives:1.Listen and repeat: listen carefully and repeat to the customer.2. 
Acknowledge: acknowledge the customer's feelings. 3. Apologize: apologize to the guest for being put into such a situation 4.Agree: It is important to agree on a solution together. 5. Thank: always thank the guest for complaining. The goal of gracious problem solving is to have the guest leave happy or otherwise satisfied with the solution to the problem. That is why it is vital to involve the customer in the determination of a solution. When something has happened to guests that shouldn't have happened, they need to be compensated in some way whether it is compensation for a night's lodging, a meal, or a future ticket, room, or meal. There are no formula which answers to the appropriate amount of compensation to a guest who has experienced a problem. That is why it is always advisable to ask the guests how they would like the issue resolved. On the other hand, difficult customers are often merely expressing a need, although they may be choosing an inappropriate and impolite way of communicating it is important to remember that they are being difficult for their own reasons, not because of the customer service staff. By working to meet these needs, the staff can go a long way toward being successful with a guest who is being troublesome or otherwise challenging. Difficult guests come in all shapes, sizes and varieties for examples: The demanding guest, The nasty or obnoxious person, The very particular or picky person, The constant critic, The nonstop talker, The condescending guest, The indecisive person, The intoxicated individual, The argumentative customer, The rude or impolite guest, Don't take it personally. This is the hardest skill to learn. Remember that difficult people are not attacking you personally (even though it may seem that they are).Remain calm. Listen carefully. This is easy advice to give, but in practice very difficult to do. Use you effective listening skills by repeating back what you have heard, paraphrasing the guest, making sure you have heard him/her correctly. Focus on the problem, not the person. If possible, go to a quiet area. Sit down, be a problem solver. Try to figure out what this person needs, and satisfy this need in some way, if you can. Let the customer know what you can do not what you can't do. Be positive. Reward yourself for turning a difficult customer into a happy one. Pat yourself on the back. Know that you have accomplished an amazing feat. You are a customer service hero. When all else fails, ask for help. Involve your supervisor when you find yourself confronted with a difficult situation that you don't know how to handle. The above the discussions have shown that the relationship between the mastery of foreign languages especially English and the development in hospitality and tourism industries is very close. I would like to point out that mastering foreign languages such as English, Mandarin, Arabic, French, Japanese and others is compulsory.

\section{Conclusion}

I think all the explanations have shown us that the AKPAR NHI students have chosen their learning strategies in according to their own preferences and they have done some activities in developing hospitality and tourism industries beforehand. So, the aims of this research have been met by relating the facts and the supporting theoretical reviews. 
In conclusion, the AKPAR NHI students learning strategies are divided into three main areas those at home, at campus, and outdoors. The same strategies in developing hospitality and tourism industries are divided into three areas those are at home, at campus, and outdoors. I would like to recommend that English as the first international language should be mastered. Learning foreign languages should also learn their cultural background. Developing hospitality and tourism industries worldwide should involve foreign languages mastery.

To end this discussion, the writer would like to point out that this research has some weaknesses in terms of time management which was so limited in doing the investigation, and the evaluations of the investigation research. Therefore, I would propose that some deep investigations towards the involvement of foreign languages mastery in developing hospitality and tourism industries be carried out in the future by other researchers.

\section{References}

Alwasilah dan Sudarya. (1991). Dasar-dasar Linguistik. CV. Tunas Putra Bandung.

Chammot, A.U. (1987). The learning Strategies. Prentice Hall.

Ellis, G.(1990). Learning To learn. Cambridge. Cambridge Press.

Gardner,R.C. and Lambert, W.E. (1985). Social psychology and Second Language. London. Edward. London

Martin, B William . (2003). Providing Quality Service prentice hall. Uk.

Kandampully J.(2002). Services Management. The new Paradigm in hospitality. Pearson Education Australia.

Lukmani, Y. (1972). Motivation to learn and Language proficiency. Language learning 22. P.261-273.

Nisbet, J. (1986). Learning Strategies. London.

Oxford. (1990). Learning strategies. Boston. Massachusset.

Rahayu, Acep U.R. (1995). Bottom-up and Top-down Reading. Leeds.

Rahayu, Acep U.R. (2008). Strategi membaca mahasiswa D-4 dan pascasarjana STP bandung. Proyek Diknas dan Litabmas. Bandung.

Rubin. (1987). Learner's strategies. London. Prentice Hall.

Sugono, D.(1994). Verba dan komplementasinya. Pusat Pembinaan dan Pengembangan Bahasa. Jakarta.

Wenden. (1987). Leraner's strategies in language learning. Prentice hall. International. 